\title{
DEMAND FOR FUEL WOOD AND ITS SUBSTITUTION POSSIBILITIES IN URBAN AREAS OF UMUAHIA METROPOLIS OF ABIA STATE, NIGERIA
}

\author{
${ }^{1}$ Iheke, O. R. and J. Osuji ${ }^{2}$ \\ Department of Agricultural Economics \\ Michael Okpara University of Agriculture, Umudike, Nigeria \\ 1ralphiheke@gmail.com, iheke.onwuchekwa@mouau.edu.ng \\ ºsujijoseph@yahoo.com
}

\begin{abstract}
Fuel wood has grown in importance as a major source of energy for most households especially for cooking. An estimated 2.5 to 3.0 billion people rely on wood for fuel, both for warmth and food preparation. In Africa, wood is depended upon for up to $58 \%$ of all energy requirements and in many savanna areas, demand for fuel wood far exceeds the rate of growth. With the hike in price of other energy sources especially petroleum products due to partial withdrawal of subsidy and epileptic electricity and power outages, fuel wood demand and usage has been on the increase. The situation provides the rationale for this study. Specifically, the study analyzed pattern of fuel wood utilization, and substitution by the households, preference of energy source by the households, and determinants of demand for fuel wood. Purposive and random sampling technique was used in choosing the sample. The data collected using structured questionnaire and interview schedules were analyzed using descriptive statistical tools such as frequency tables, percentages and inferential statistical tools such as regression analysis. Results showed that the predominant use of fuel wood was for cooking, following by roasting and frying and that the major substitute for fuel wood was kerosene followed by cooking gas. The most preferred energy type by the households was cooking gas which was ranked first, followed by kerosene which was ranked second. The significant variable influencing the quantity of fuel wood demanded were gender, household size, income, years of education, price of fuel wood, and price of kerosene which is the major substitute for fuel wood. The own price elasticity was less than one, indicating that the demand for fuel wood was inelastic. There should be a revisit in the withdrawal of subsidy of kerosene and cooking gas used by the average Nigerian, in the face of rising inflation which reduces the purchasing power of households. This is so to ensure sustainability of forests from where this fuel wood are being harvested and avoid degradation of the environment. The Nigeria Government should hasten to invest in the development of cooking gas, as an alternative fuel source, instead of continuous flaring of this gas, which contributes to global warming.
\end{abstract}

KEY WORDS: Demand, Fuel wood, Substitution, Elasticity

\section{Academic Discipline And Sub-Disciplines}

Agriculture, Economics

\section{SUBJECT CLASSIFICATION}

Agricultural Economics

\section{TYPE (METHOD/APPROACH)}

Survey/Interview

\section{Council for Innovative Research}

Peer Review Research Publishing System

Journal: Journal of Social Sciences Research

Vol. 7, No. 1

jssreditor.cir@gmail.com

www.jssronline.com 


\section{INTRODUCTION}

Fuel wood has remained a dominant source of energy for most households. Heltberg et al., (2000) and William (2003) noted that approximately 2.5 to 3 billion people ( $40-50$ percent of the world's total) rely on wood for fuel, both for warmth and food preparation. In Africa, wood is depended upon for up to 58 percent of all energy requirements and in many savanna areas, demand for fuel wood supplies far exceeds the growth rate trees used for fuel wood. According to Gbadegesin and Olorunfemi (2011), the regional analysis of the use of fuel wood as a major source of energy indicate that in Eastern, Western and Southern Africa, more than 90 percent of rural households depend on fuel wood for energy. Most rural and urban people in Africa, Asia, and Latin America still rely on trees and woody vegetation to meet their basic energy needs (Makame, 2007).

In Nigeria, fuel wood has grown in importance as a source of energy for cooking, heating and other uses. Thus, there has been rising demand for fuel wood. Among the factors contributing to the high demand for fuel wood in Nigeria are hike in prices of petroleum products, fuel wood affordability, and availability. Nigeria as a whole suffer from sporadic fuel scarcities, strikes and labour unrest during price hike of petroleum products. The partial withdrawal of petroleum subsidy has exacerbated the problem, with people opting for fuel wood. According to Sambo (2005), Nigeria's fuel wood consumption is estimated at 80 million cubic metres (about 25 million tonnes) annually for cooking and domestic uses. The Solar Cooking Archive (2011) in Zaku et al. (2013) put the estimate of Nigeria's fuel wood consumption as percentage of total energy at about 87 percent.

According to Babanyara and Saleh (2010), the demand for fuel wood in Nigeria's urban areas has been increasing due to the fact that other sources of energy are experiencing hike in prices and this has continuously pushed many households down the energy ladder. They noted that despite the availability of modern energy sources to some city dwellers, the majority of the migrants from rural to urban areas (whom in Nigeria accounted for $65 \%$ of the urban population in 1991 to more than $70 \%$ in 2006) cannot afford them. For these people, wood remains their fuel but instead of collecting it, they now have to buy from vendors. This signifies that fuel wood is more affordable than other conventional fuel such as kerosene and cooking gas and other sources of energy.

Energy has a major impact on every aspect of social-economic life. Reliable and clean energy supply is a pre-requisite for sustainable development and the fight against poverty. Energy, especially electricity is important in raising the living standard of the people, but the epileptic electricity supply and power outages in Nigeria of not less than 10 hours per day have made this a mirage (Onyegebu, 2003). The use of fuel wood in urban areas of Nigeria is further made possible due to improved transportation infrastructure which made possible the movement of large quantities of fuel wood from the rural areas to the urban centres. The business of fuel wood trading is also reported to be a very profitable business (Ebe, 2006).

Urban areas provide greater opportunity for substituting other fuel for fuel wood because the alternatives are more a ccessible and urban dwellers are accustomed to paying cash for energy. Dovie et al. (2004), An et al. (2002), Karekezi and Majoro (2002) and Israel (2002) noted that the main reasons for lack of inter-fuel substitution is that household choice and use of a given source of fuel hinges on a host of socioeconomic (e.g. income, and wealth), demographic (e.g. family size, household composition, lifestyle, and culture) and location attributes (e.g. proximity to sources of modern and traditional fuels) in addition to fuel wood availability.

The relative prices of different energy sources strongly influence inter-fuel substitution. In an economy where fuel oil prices are subsidized the commercial development of other alternative source need to be subsidized. This is necessary because change in relative prices can have substantial effect on consumers' choice of fuel (Siddayao, 1993). Karekezi and Majoro (2002) have noted that urban poverty in Africa is growing with gap between poor and the rich getting wider and the proportion of the poor getting poorer. Urbanization is an important determinant of both the quantity and the type of fuel used in the developing countries. In general, urbanization leads to higher level of household energy consumption. Although, it is difficult to separate the effect of urbanization from that of increased income levels that generally accompanying urbanization. Nevertheless, the use of traditional fuel in many cities remains high among low income groups (Oladosu and Adegbulugbe, 1994).

Given the above scenario, it has become imperative to quantitatively assess and analyze the demand for fuel wood and its substitution possibilities in Umuahia Metropolis of Abia State of Nigeria. Specifically, the study examined the socioeconomic characteristics of the respondents, ascertained the determinants of demand for fuel wood in the area of study, determined the elasticity of demand for fuel wood, the preference of consumers (substitutes) for alternative fuel sources and the major constraints to the usage of fuel wood in the study area.

\section{METHODOLOGY}

This study was conducted in Umuahia. Umuahia is the capital of Abia State in Southeastern Nigeria. Umuahia comprises two local government areas: Umuahia North and Umuahia South. These local governments are also composed of clans such as the Umuopara, Ibeku, Olokoro, Ubakala and Ohuhu communities. The study area lies within latitude $5^{\circ} 23^{\prime}$ and $5^{\circ} 45^{\prime}$ North of the Equator and longitude $70^{\circ} 23^{\prime}$ and $70^{\circ} 73^{\prime}$ East of the Greenwich Meridian. Umuahia has a population of 359,230 people (NPC, 2006), and is well known as being an agricultural market center since 1916. It is also a railway collecting point for crops such as yams, cassava, corn (maize), taro, citrus fruits, and palm oil and kernels. The rural inhabitants are predominantly farmers and the major crops grown include cassava, melon, maize, yam, cocoyam, vegetables etc. and livestock such as goats, sheep, poultry are also kept but on a small scale basis. 
Purposive and random sampling technique was used in choosing the sample. In the first stage, 3 clans in Umuahia were purposively selected based on their location. These were Ibeku, Olokoro and Ubakala. The second stage involves the purposive selection of all households using fuel wood. The list of these households in each clan formed the respective sampling frames. In the last stage, 25 households from each clan were randomly selected, giving a sample of 75 respondents. However, 67 questionnaires were retrieved out of the 70 distributed and 60 were found useful and used for the analysis. The data collected using structured questionnaire and interview schedules were analyzed using descriptive statistical tools such as frequency tables, percentages and inferential statistical tools such as regression analysis. For the factors influencing the demand for fuelwood, the implicit ordinry least squares regression model analyzed is specified as :

$Y=f\left(X_{1}, X_{2}, X_{3}, X_{3}, X_{4}, X_{5}, X_{6}\right)$

Where $Y=$ quantity of fuelwood demand (measured in $\mathrm{kg}$ ), $X_{1}=$ Gender (a dummy, with zero for female and unity for male), $X_{2}=$ household size (number), $X_{3}=$ income (measured in naira), $X=$ years of educational attainment, $X_{5}=$ price of fuelwood (measured in naira), and price of fuelwood substitute (measured in naira)

\section{RESULTS AND DISCUSSION}

\subsection{Pattern of fuel wood utilization}

The distribution of the respondents based on pattern of fuel wood utilization is presented in Table 1. The Table showed that the predominant use of fuel wood was for cooking, following by roasting and frying. This result is consistent with the findings of Ononja and Emodi (2012). Cooking food for consumption has over time remained the prevalent use of fuel wood for most households especially for low income households.

Table 1: Distribution of households according to pattern of utilization of fuel wood

\begin{tabular}{lll}
\hline Use of fuel wood & Frequency $^{*}$ & Percentage \\
\hline Cooking & 44 & 77.33 \\
Baking & 5 & 8.33 \\
Roasting & 27 & 45.00 \\
Frying & 26 & 43.33 \\
Ironing & 12 & 20.00 \\
\hline
\end{tabular}

Source: Field Survey Data, 2012.

*Multiple responses recorded

\subsection{Energy substitution by the households}

The distribution of the respondents based on alternative source of energy other than fuel wood use is presented in Table 2. The result shows that the major substitute for fuel wood was kerosene followed by cooking gas. Kerosene is readily available and more affordable than the other sources and this explains its high rate of use by the households. The low use of electricity could have resulted due to the epileptic power supply as witnessed in the country. Though electricity is recognized as being crucial in raising the living standard of the people, epileptic power supply and incessant power outages have made this a mirage (Onyegebu, 2003).

Table 2: Alternative energy source used by the households

\begin{tabular}{lll}
\hline Variable & Frequency * & Percentage \\
\hline Kerosene stove & 58 & 96.67 \\
Cooking gas & 17 & 28.33 \\
Electric stove & 12 & 20.00 \\
\hline
\end{tabular}

Source: Field Survey Data, 2012.

*Multiple responses recorded

\subsection{Preference of energy source by the households}

The households were asked to rank the various energy sources based on their preferences, ceteris paribus. The result is presented in Table 3. The result showed that the most preferred energy type by the households was cooking gas which was ranked first, followed by kerosene which was ranked second. The question is then why the high rate of use of fuel wood? The increase in demand for fuel wood in Nigeria's urban areas as explained by Babanyara and Saleh (2010) is due to the fact that other sources of energy are experiencing hike in prices and this has continuously pushed many households down the energy ladder; and despite the availability of modern energy sources to some city dwellers, the majority of them cannot afford them. 
Table 3: Ranking of energy sources by the respondents

\begin{tabular}{lllll}
\hline Energy type & Rank1 & Rank 2 & Rank 3 & Rank 4 \\
\hline Fuel wood & 0 & 8 & 32 & 40 \\
Cooking gas & 56 & 13 & 15 & 2 \\
Kerosene & 3 & 35 & 9 & 15 \\
Electricity & 1 & 4 & 4 & 3 \\
\hline Total & 60 & 60 & 60 & 60 \\
\hline
\end{tabular}

Source: Field Survey Data, 2012.

\subsection{Determinants of demand for fuel wood}

The estimated determinants of the demand for fuel wood is presented in Table 4. The exponential function al form was chosen as the lead equation. This choice was based on econometric and statistical reasons - high magnitude of the coefficient of determination $\left(R^{2}\right)$, the number of significant variables as well as the conformity of the signs borne by the coefficients of these variables to a priori expectation, and the significance of the $f$-ratio. The coefficient of the multiple determination was 0.8639 indicating that is $86.39 \%$ of variations in the quantity of wood demanded by the households were explained by the variable included in the model. The F-ratios of the estimated functions were statistically significant, indicating reasonable overall significance and high explanatory power of the model. The significant variable influencing the quantity of fire-wood demand were gender, household size, income, years of education, price of fuel wood, price of fuel wood substitute.

Table 4: Determinants of demand for fuel wood

\begin{tabular}{|c|c|c|c|c|}
\hline Variation & Linear & Exponential+ & Double log & Semi-log \\
\hline \multirow[t]{2}{*}{ Intercept } & 38.846 & 3.776 & 2.399 & -51.950 \\
\hline & $(6.04)^{* * *}$ & $(4.24)^{\star \star \star}$ & $(8.52)^{\star * *}$ & $(-2.61)^{\star * *}$ \\
\hline \multirow[t]{2}{*}{ Gender $\left(\mathrm{X}_{1}\right)$} & 0.097 & -0.035 & -0.073 & -4.935 \\
\hline & $(0.81)$ & $(-2.98)^{\star \star \star}$ & $(-2.32)^{\star \star *}$ & $(-2.22)^{\star *}$ \\
\hline \multirow{2}{*}{ Household size $\left(X_{2}\right)$} & -1.187 & 2.310 & 0.001 & -0.238 \\
\hline & $(1.46)$ & $(2.12)^{* *}$ & $(0.05)$ & $(-0.15)$ \\
\hline \multirow[t]{2}{*}{ Income $\left(X_{3}\right)$} & $1.360 . e^{-5}$ & -0.114 & 0.094 & 7.111 \\
\hline & $(1.63)$ & $(-7.38)^{\star \star \star}$ & $(2.43)^{\star \star \star}$ & $(2.61)^{\star \star \star}$ \\
\hline \multirow[t]{2}{*}{ Years of education $\left(X_{4}\right)$} & -5.433 & -0.080 & -0.026 & 0.488 \\
\hline & $(-1.91)^{*}$ & $(-1.97)^{*}$ & $(-0.72)$ & $(0.20)$ \\
\hline \multirow[t]{2}{*}{ Price of Fire-wood in naira $\left(X_{5}\right)$} & -0.018 & $-2.579 e-4$ & -0.201 & -13.666 \\
\hline & $(-5.86)^{\star \star \star}$ & $(-5.86)^{* * *}$ & $(-6.00)$ & $(-5.77)$ \\
\hline \multirow[t]{2}{*}{ Price of substitute - kerosene $\left(\mathrm{X}_{6}\right)$} & 0.682 & 0.009 & 0.085 & 5.746 \\
\hline & $(2.36)^{\star \star *}$ & $(2.14)^{\star * \star}$ & $(2.07)^{\star \star}$ & $(1.96)^{*}$ \\
\hline $\mathrm{R}^{2}$ & 0.5515 & 0.8639 & 0.5588 & 0.5349 \\
\hline $\mathrm{R}^{-2}$ & 0.4984 & 0.8118 & 0.5064 & 0.4805 \\
\hline F-ratio & $6.15^{* \star *}$ & $21.55^{\star \star \star}$ & $6.90^{* \star *}$ & $5.12^{\star \star \star}$ \\
\hline
\end{tabular}

Source: Computed from Survey data, 2012.

${ }^{* * *}=$ Significant at 1 percent, ${ }^{* *}=$ Significant at 5 percent, ${ }^{*}=$ Significant at 10 percent,$+=$ lead equation, $(\ldots)=\mathrm{t}-$ ratios

The coefficient of gender was significant at $1 \%$ and negatively related to quantity of fuel wood demanded. Since gender was measured as a dummy with unity for male and zero for female, this implies that female used more fuel wood than male. This result shows the role of females in the upkeep of the family, especially in food preparation for the family.

The coefficient of household size was significant $5 \%$ and positively related to the quantity of fuel wood demanded. This implies that the larger the household size the more demand for firewood because large household size may mean more mouth to feed and greater quantity of food to be prepared. Hence, the larger quantity of fuel wood demanded. 
The coefficient of income was significant at 1 percent and negatively related to the quantity of fuel wood demanded. This implies that as income increases, the quantity of fuel wood demanded decreases. This does not conforms to a prior expectation as economic theory postulates positively relationship between income and quantity demanded. However, the inverse relationship between income and quantity of fuel wood demanded could be as a result of substitution of fuel wood for other energy sources as a result of increased income which made it possible for the households to afford alternative and costlier energy sources.

The coefficient of years of education attainment was significant at $10 \%$ level of probability and negatively related to quantity of fuel wood demanded. This implies that the quantity of fuel wood demanded decreases with higher educational attainment. This could be that higher educational attainment leads to better jobs and hence higher income, leading to substitution of fuel wood with alternative energy sources like kerosene, cooking gas, etc.

The coefficient of the price of fire wood was significant at $1 \%$ level of probability and negatively related to the quantity of fuel wood demanded. This implies that an increase in price of the fire wood may lead to decrease in quantity of fire wood demanded by the households which will require the households to seek for an alternative source of energy. This satisfies the first law of demand.

The coefficient of the price of fuel wood substitute was significant at $1 \%$ probability level and positively related to the quantity of fire wood demanded. This result implies that as the price of fuel wood substitute increases, the demand for fuel wood would increase. As the price of alternative energy sources increases as is the case at present, households would turn to cheaper source of energy which is inevitably fuel wood.

The own price elasticity was less than one, indicating that the demand for fuel wood was inelastic. This implies that changes in price have a relatively small effect on the quantity of the fuel wood demanded.

\section{CONCLUSION AND RECOMMENDATIONS}

It could be concluded from this study that fuelwood is a major energy utilized by households in the study area, predominantly for cooking, roasting and frying in the face of escalating prices of alternative energy sources. Also with a rise in income, ceteris paribus, the households would substitute fuelwood for cooking gas as the most preferred energy source. There should be a revisit in the withdrawal of subsidy of kerosene and cooking gas used by the average Nigerian, in the face of rising inflation which reduces the purchasing power of households. This is so to ensure sustainability of forests from where this fuelwood are being harvested and avoid degradation of the environment. The Nigeria Government should hasten to invest in the development of cooking gas, as an alternative fuel source, instead of continuous flaring of this gas, which contributes to global warming.

\section{ACKNOWLEDGMENTS}

Our thanks to the experts who have contributed towards development of the template.

\section{REFERENCES}

[1] An, L., Lupi, F., Liu, J., Linderman, M.A., \& Huang, J. 2002. Modeling the choice to switch from fuelwood to electricity: implications for Giant Panda habitat conservation, Ecological Economics, 42: 445-57.

[2] Babanyara, Y. Y and Saleh, U. F. 2010. Urbanisation and the Choice of Fuel Wood as a Source of Energy in Nigeria. Journal of Human Ecology, 31(1): 19-26

[3] Dovie, D.B.K., Witkowski, E.T.F., and Shackleton, C.M. 2004. The fuelwood crisis in Southern Africa: relating fuelwood use to livelihoods in a rural village, GeoJournal, 60: 123-139.

[4] Ebe, F. E. 2006. Economic study of fuelwood marketing and consumption in Enugu State, Nigeria. A Ph.D Research findings presented to the Department of Agricultural Economics, University of Nigeria, Nsukka. August.

[5] Gbadegesin, A. and Olorunfemi, F. 2011. Socio-Economic Aspects of Fuel Wood Business in the Forest and Savanna Zones of Nigeria: Implications for Forest Sustainability and Adaptation to Climate Change. Global Journal of Human Social Science. 11 (1): $45-56$.

[6] Heltberg, R., Arndt, T. C. and Sekhar, N. U. 2000. Fuelwood Consumption and Forest Degradation: A Household Model for Domestic Energy Substitution in Rural India. Land Economics 76 (2): 213-232

[7] Israel, D., 2002.. Fuel choice in developing countries: evidence from Bolivia", Economic Development and Cultural Change, 50: 865-890

[8] Karekezi, S and Majoro, L. 2002. improving modern energy service for Africa urban poor. Energy policy 30:10151028.

[9] Makame, O. M. 2007. Adoption of improved stoves and deforestation in Zanzibar. Management of Environmental Quality: An International Journal, 183: 353-365.

[10] National Population Commission (Nigeria) 2006. National Policy on Population for Sustainable Development 2006, NPC report series No.1, Abuja. 
[11] Oladosu, G.A and Adegbulugbe, A.O. 1994. Nigeria Household energy Sector. Issues Demand Frontiers Energy policy 22 (6): 538-549.

[12] Onoja, A. O. and Emodi, A. I. 2012. Economic Analysis of Fuelwood Production and Consumption: Evidence from a Nigerian State. British Journal of Management \& Economics, 2(1): 13-23

[13] Onyegebu, S. O. 2003. Renewable Energy Potentials and Rural energy Scenario in Nigeria In: Renewable Energy for Rural Industrialization and Development in Nigeria. United Nations Industrial Development Organization and Energy Commission of Nigeria (UNIDO/ECN) 2003

[14] Sambo, A. S. 2005. Renewable energy for rural development: The Nigerian perspective. ISESCO: Science and Technology Vision, 1: 12-22.

[15] Siddayao, C. M. 1993. Report 1990: The growing role of electricity in the energy spectrum: World Energy Council, London, UK. Energy Policy, 1993, 21 (1): 93-93

[16] The Solar Cooking Archive 2011. Fuelwood as percentage of energy consumption in developing countries. Retrieved on 23th August, 2012 from:http://solarcooking.org/fuelwood.htm.http://solarcooking.org/fuelwood.htm.

[17] Williams, M. 2003. Deforesting the earth from Prehistory to Global Crisis. "American Forests".University of Chicago Press

[18] Zaku, S. G., Kabir, A., Tukur, A. A. and Jimento, I. G. 2013. Wood fuel consumption in Nigeria and the energy ladder: A review of fuel wood use in Kaduna State. Journal of Petroleum Technology and Alternative Fuels, 4(5): 85-89.

\section{Author' biography with Photo}

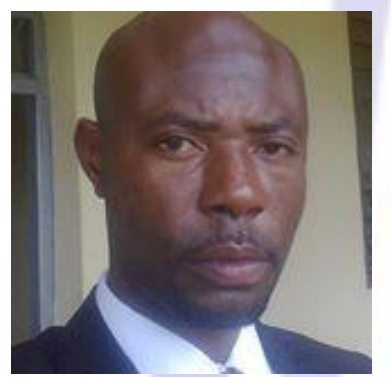

The first author, Dr. O. R. Iheke, is a lecturer in the Department of Agricultural Economics, Michael Okpara University of Agriculture, Umudike in Abia State of Nigeria; while the coauthor, Mr. J. Osuji is a student of the Department of Agricultural Economics, Michael Okpara University of Agriculture, Umudike in Abia State of Nigeria.

Dr. O. R. Iheke

N/B: Mr. Osuji is current unavailable as to get his photo. 